\title{
Bioelectrooxidation of Ethanol Using NAD-Dependent Alcohol Dehydrogenase on Oxidized Flexible Carbon Fiber Arrays
}

\author{
Andressa R. Pereira, ${ }^{a}$ João C. P. de Souza, ${ }^{a, b}$ Andressa D. Gonçalves, ${ }^{a}$ \\ Kamila C. Pagnoncelli ${ }^{a}$ and Frank N. Crespilho $* a$ \\ aInstituto de Química de São Carlos, Universidade de São Paulo, 13560-970 São Carlos-SP, Brazil \\ ${ }^{b}$ Instituto Federal Goiano, Campus Rio Verde, Rodovia Sul Goiana km 1, 75901-970 Rio Verde-GO, Brazil
}

\begin{abstract}
Hierarchical 3-dimensional flexible carbon fiber (FCF) array is a candidate as flexible electrode for enzyme electrochemistry, with interesting properties for application in enzymatic biofuel cell and implantable biosensors. Here, we show the fabrication of oxidized FCF electrode (FCFO) based on chemical surface treatment, a wet oxidation method by using permanganate ions. Compared with pristine FCF, FCFO is rougher; the scratches become wider and deeper, with some defects in the basal planes and some cracked structures. X-ray photoelectron spectroscopy data suggests a correlation between the carbon structures and the appearance of chemical groups containing oxygen atoms. Finally, we show how the bioelectrocatalysis of ethanol by using FCFO arrays modified with NAD-dependent alcohol dehydrogenase $(\mathrm{ADH})$ is positively influenced by the fibers treatment oxidation process.
\end{abstract}

Keywords: alcohol dehydrogenase, ethanol oxidation, flexible carbon fiber

\section{Introduction}

Carbon and its inorganic compounds are widely exploited in electrochemistry field as solid electrodes in the form of diamond, graphite, fullerene, carbon nanotubes, and more recently, graphene. ${ }^{1,2}$ Flexible carbon fibers (FCFs) have a structure similar to graphite, in which there are $\mathrm{sp}^{2}$-hybridized carbon atoms in 2D layers of a stacked graphene-like material. The subtle difference between graphite and FCFs is in their micro and nanostructural organization, in which the carbon layers are turbostratically stacked within the FCFs, as shown in Figure $1 .^{3}$ Both types of sheets of carbon atoms are arranged in a regular hexagonal pattern. The difference is the way these carbon sheets interlock. In turbostratic FCFs, the sheets of carbon atoms are haphazardly folded, leading to a crumpled-like structure. It is, therefore, possible to produce graphene oxides from FCF by modified Hummers' method and hence create defects in the FCF surface. ${ }^{4}$

FCFs have served as a platform for fabrication of enzyme electrodes. ${ }^{5,6}$ Modification of the surface of FCFs can improve the bio-electrochemical performance of such bioelectrodes. ${ }^{7}$ The enzyme electrode is a miniature

*e-mail: frankcrespilho@iqsc.usp.br chemical transducer that combining an electrochemical procedure with immobilized enzyme activity; for instance, there is glucose oxidase immobilized on a gel to measure the concentration of glucose in biological system. ${ }^{8}$ In particular, since 2013 when FCF array was used to intravenous implantable glucose/dioxygen biofuel $^{9}$, we have successfully applied FCF arrays as flexible electrodes for high-performance glucose dehydrogenase bioanodes, ${ }^{7}$ glucose biochip based for in vivo diabetes evaluation in rats ${ }^{10}$ and enzyme biofuel cells. ${ }^{11,12}$ The combination of carbon-based electrodes and enzymes is used to investigate enzymatic reactions, kinetics and thermodynamics. ${ }^{12}$

As NAD-dependent enzymes on electrode are concerned, the applicability of FCF is still a challenge. The electrooxidation of $\beta$-nicotinamide adenine dinucleotide $(\mathrm{NADH})$ is necessary to regenerate NAD-dependent enzymes. However, at bare carbon-based electrodes, the electrochemical oxidation of NADH is irreversible and requires a high overpotential, e.g., $1.1 \mathrm{~V}$ (vs. saturated calomel electrode-SCE) at $\mathrm{pH} 7.0 .^{13,14}$ The efficient reversible recycling of NADH is of particular interest in the construction of dehydrogenase biosensors, biofuel cell bioanodes and fine chemicals industry. ${ }^{11,12,15}$ Furthermore, the electrochemical oxidation of NADH at low overpotentials is an actual and exciting scientific 


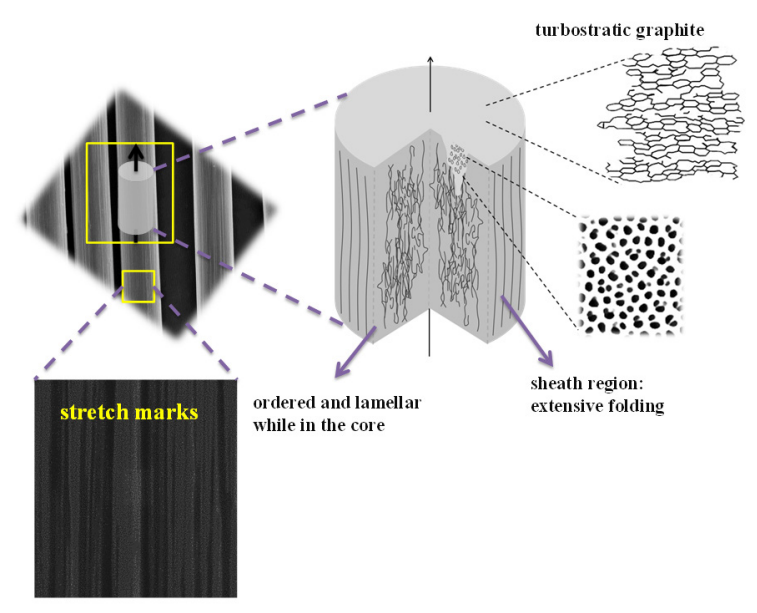

Figure 1. Structures for a single flexible carbon fiber (FCF) from its array. Here, it is summarized some morphological characteristics, showing tilt, twist boundaries, porosity and overlapping boundaries. Graphitic layers form the basic structural units in the shape of ribbons of $6 \mathrm{~nm}$ average width and a length of several hundred nanometers. From 10 to 14 such ribbons pack in bundles to form fibrils observed in electron micrographs of a single FCF. The complete FCF description can be found in reference 10 .

problem, since more than 300 dehydrogenases are known whose activities are dependent on NADH or NADPH as cofactors. ${ }^{16}$ Quinones-modified electrodes or soluble quinone-based redox mediator have been reported to oxidize $\mathrm{NADH}$, including pyrroloquinoline quinone (PQQ), ${ }^{17,18}$ 9,10-phenanthraquinone ${ }^{19}$ and naphthoquinone redox polymer (NQ-LPEI). ${ }^{20}$ Newly, NAD-dependent glucose dehydrogenase $(\mathrm{GDH})$ bioelectrodes were utilized as glucose bioanodes with laccase $\mathrm{O}_{2}$-reducing biocathodes in a glucose $/ \mathrm{O}_{2}$ biofuel cell. ${ }^{20}$

Here, we report important advances to obtain active FCF arrays for the build up of NAD-dependent dehydrogenase enzyme electrodes. The experimental setup is based on the wet oxidation treatment of FCF by using permanganate ions; the methodology is fast, reproducible and with onepot reaction approach. The oxidized and exfoliated carbon structures on FCF electrode shows excellent conditions to immobilize alcohol dehydrogenase (ADH). Our interest in this type of enzyme consist that NAD-dependent $\mathrm{ADH}$ catalyzes the reversible interconversion of alcohols to aldehydes or ketones and can be utilized as anodic biocatalysts in biofuel cells. Also, biofuel cells with high electromotive forces could be constructed using these enzymes, since the formal potential $\left(\mathrm{E}^{\circ}\right)$ of the NAD/NADH is $-315 \mathrm{mV} v s$. standard hydrogen electrode (NHE) ( $\mathrm{pH} 7.0$, $25^{\circ} \mathrm{C}$ ). Based on X-ray photoelectron spectroscopy (XPS) we have strong evidences that after chemical treatment, the fibers shows defects composed by oxygenated species. We propose that FCF-oxidized array (FCFO) electrodes modified with ADH (FCFO-ADH) is very promising for NADH oxidation, consequently for application in ethanol bioelectrooxidation. Furthermore, we emphasize here that a deeply discussion regarding the "quinone-like" behavior of the fiber surface shall be addressed in details.

\section{Experimental}

\section{Materials}

Alcohol dehydrogenase from Saccharomyces cerevisiae and absolute ethanol were purchased from Sigma-Aldrich and used without further purification. FCF electrodes were extracted from a flexible carbon cloth (CCS200), as described in literature. ${ }^{4} \mathrm{NaH}_{2} \mathrm{PO}_{4} / \mathrm{Na}_{2} \mathrm{HPO}_{4}$ salts utilized for the preparation of $0.1 \mathrm{~mol} \mathrm{~L}^{-1}$ buffer solution, sulfuric acid and potassium permanganate were purchased from Synth. Nicotinamide adenine dinucleotide free acid was purchased from Merck.

\section{Chemical surface treatment of carbon fibers}

Chemical surface treatment was carried out by immersion of $0.5 \mathrm{~g}$ of FCF in a $120 \mathrm{~mL}$ of $1.0 \mathrm{~mol} \mathrm{~L}^{-1} \mathrm{H}_{2} \mathrm{SO}_{4}$ and $24.5 \mathrm{~mol} \mathrm{~L}^{-1} \mathrm{KMnO}_{4}$ (aq). This mixture was kept in an ultrasound bath for 3 hours. The FCF was then washed with $\mathrm{HCl}(37 \%)$ once in order to remove residual $\mathrm{MnO}_{2}$, and then cleaned with ultrapure water to remove excess acid. The treated FCF (FCFO) was dried under vacuum. The morphologies of the fibers obtained from chemical surface treatment were evaluated by field-emission scanning electron microscopy (FEG-SEM, FEI Magellan 400L).

The formation of oxygenated carbon functional groups was confirmed by XPS (UNI-SPECS UHV System). The experiments were carried out at a pressure of less than $10^{-7} \mathrm{~Pa}$. The $\mathrm{Mg} \mathrm{K} \alpha$ line $(\mathrm{h} v=1253.6 \mathrm{eV})$ was used as the X-ray source and the analyzer pass was set to $10 \mathrm{eV}$. The spectra were fitted using multiple Voigt profiles. The inelastic background of the $\mathrm{C} 1 \mathrm{~s}$ and $\mathrm{O} 1 \mathrm{~s}$ electron corelevels were subtracted by Shirley's method. The binding energy scale of the spectra was corrected using the $\mathrm{C} 1 \mathrm{~s}$ hydrocarbon component of the fixed value of $285.0 \mathrm{eV}$. The width at half maximum (FWHM) varied between 1.2 and $2.1 \mathrm{eV}$ and the accuracy of the peak positions was $\pm 0.1 \mathrm{eV}$.

\section{Enzyme immobilization: FCFO-ADH electrodes}

Before adsorption of the enzyme, the FCFs were treated according to the process outlined above. The FCFO-ADH bioelectrodes were prepared via physical adsorption ${ }^{12,21}$ of the enzyme. The complete protocols for enzyme immobilization has been described and highlighted by our group recently. ${ }^{11,12}$ The electrodes areas $\left(\mathrm{ca} .0 .3 \mathrm{~cm}^{2}\right.$ ) were 
delimited with epoxy resin. In summary, FCFO was placed in an $\mathrm{ADH}$ solution $\left(8 \mathrm{mg} \mathrm{mL}^{-1}\right.$ in sodium phosphate buffer, $\mathrm{pH} 7.5$ ) for 24 hours at $4^{\circ} \mathrm{C}$. Then, $20 \mu \mathrm{L}$ of Nafion ${ }^{\mathrm{TM}}(2.5 \%)$ was dropped onto the FCFO containing the adsorbed ADH, and the bioelectrode was vacuum dried.

\section{Bioelectrocatalysis of ethanol}

All electrochemical experiments were performed in a conventional three-electrode cell, using a FCFO or modified electrodes (FCF-ADH and FCFO-ADH) as working electrode, an $\mathrm{Ag} / \mathrm{AgCl}^{-} \mathrm{Cl}^{-}{ }_{\text {(sat) }}$ (silver, silver chloride in saturated $\mathrm{KCl}$ ) reference electrode and a platinum wire $\left(0.5 \mathrm{~cm}^{2}\right)$ as counter electrode. For this, an Autolab PGSTAT128N Potentiostat-Galvanostat was employed. The bioelectrocatalysis experiments were carried out using cyclic voltammetry in the presence of an ethanol substrate. Cyclic voltammetry and chronoamperometry were employed and several concentrations of ethanol were also evaluated. Sodium phosphate buffer $\left(0.1 \mathrm{~mol} \mathrm{~L}^{-1}\right.$, $\mathrm{pH}$ 7.5) was used as the electrolyte in the presence of $0.6 \mathrm{mmol} \mathrm{L}^{-1} \mathrm{NAD}^{+}$. The electrolyte was purged with nitrogen for at least 10 minutes prior to the measurements. Electrochemical measurements were also carried out to obtain the bioelectrooxidation of ethanol at different temperatures (from 10 to $60^{\circ} \mathrm{C}$ ) and $\mathrm{pH}$ (from 6.0 to 9.0). The temperature of the electrolyte was varied by using a high precision thermostatic bath (GE-MultiTemp IV Thermostatic Circulator).

\section{Results and Discussion}

\section{Surface morphology and composition of pristine FCF and FCFO}

As the reaction of carbon atoms from pristine FCF with permanganate ions in solution is concerned, it is expected that the chemical oxidation of carbon surface generates significant changes, especially, in the surface atoms (composition and structure) and the morphology of the oxidized carbon. Both of these effects are present in the oxidized fibers, as discussed below.

SEM image of fibers arrays electrode is shown in Figure 2a, and FEG-SEM of pristine and treated FCF single fibers are shown in Figures $2 b$ and $2 c$, respectively. Compared to the pristine one, FCFO is rougher, the stretches are wider and deeper, and some defects were generated after treatment. Figure $2 \mathrm{~d}$ shows an amplified region of the FCF that presents a smooth and homogenous surface, while Figure 2e shows details of the defects formed on the surface that exhibit grooves with an average separation distance of $15 \mathrm{~nm}$. The defects generated are related to the oxidative process, where the basal planes on the surface are cracked allowing separation of the 2D-graphite layers in the exposed edge planes. The oxidation of carbon fibers was confirmed by XPS.
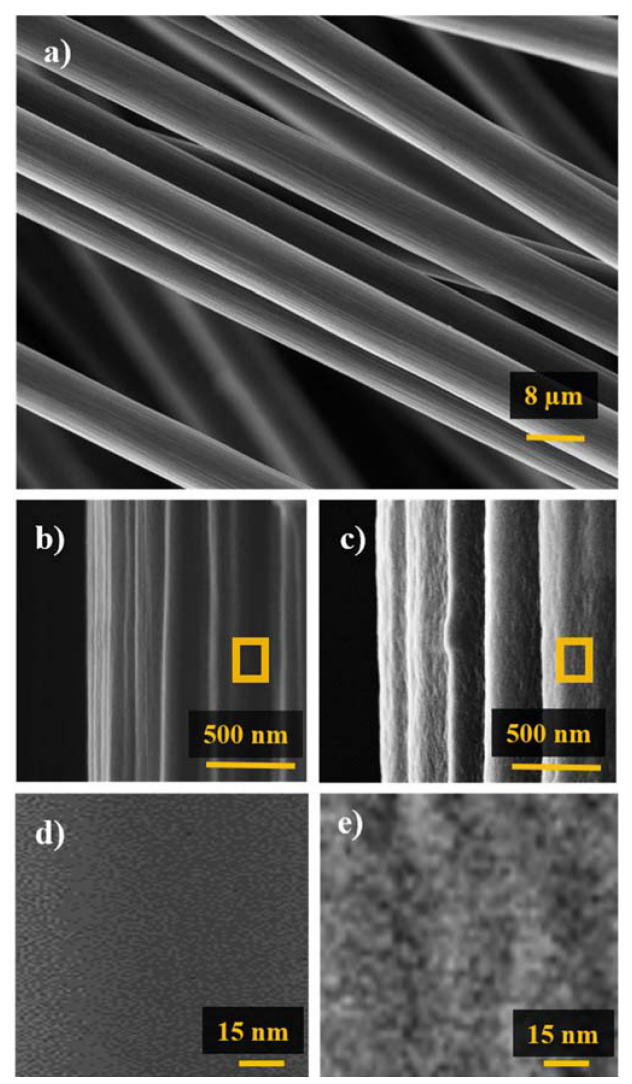

Figure 2. (a) SEM of fibers arrays; FEG-SEM of (b) pristine FCF surface; (c) FCF surface after the oxidative treatment (FCFO); (d) and (e) FCF and FCFO surface at higher magnifications, respectively.

Figures $3 \mathrm{a}$ and $3 \mathrm{~b}$ show the deconvoluted $\mathrm{C} 1 \mathrm{~s}$ region of the XPS spectra of FCF and FCFO, respectively. An increase in the number of oxygenated functional groups for FCFO compared with FCF can be seen, which is related to new spectral feature arising near $289.1 \mathrm{eV}$ (peak V) in Figure $3 b$. This peak confirms that the oxidation process occurred successfully, revealing the presence of carboxylic and ester groups $(\mathrm{O}-\mathrm{C}=\mathrm{O})$. The two samples maintain their graphitic features, presenting a higher peak at $284.7 \mathrm{eV}$ (peak I) that is related to $\mathrm{sp}^{2}$ carbon atoms. The peak at $285.5 \mathrm{eV}$ is related to $\mathrm{sp}^{3}$ hybridization of carbon. The other oxygenated functional groups are at peaks 286.7 and $287.9 \mathrm{eV}$ that correspond to $\mathrm{C}-\mathrm{O}$ and $\mathrm{C}=\mathrm{O}$ groups, respectively. We also observe peak at $290.4 \mathrm{eV}$ related to the plasmon $\pi-\pi^{*}$. The deconvoluted $\mathrm{O} 1 \mathrm{~s}$ region of the XPS spectra of FCF and FCFO are presented in Figures $3 \mathrm{c}$ and $3 \mathrm{~d}$, respectively. This data corroborate the spectra in the $\mathrm{C} 1 \mathrm{~s}$ region, showing an increase in oxidation. 
This increase in oxidation can be observed by the decrease in the intensity of the peak at $532.5 \mathrm{eV}$ that corresponds to the $\mathrm{C}-\mathrm{O}$ groups after treatment. The carbon atoms in $\mathrm{C}-\mathrm{O}$ have a lower oxidation number when compared with $\mathrm{C}=\mathrm{O}$ and $\mathrm{O}-\mathrm{C}=\mathrm{O}$ that are at peaks 531.5 and $533.7 \mathrm{eV}$ in the $\mathrm{O}$ 1s spectra. The increase of these peaks shows that FCF was oxidized. The peak at $535.3 \mathrm{eV}$ is related to adsorbed water at the FCF surface. This peak is more prominent for FCF, which shows that FCFO has higher hydrophilicity than FCF.

Carbon-oxygen bonds cause partial change of carbon atoms hybridization from $\mathrm{sp}^{2}$ to $\mathrm{sp}^{3}$. The methodology proposed here based on permanganate ions is a modification of Hummers' method to produce graphene oxide in suspension. Hummers' method consists in the oxidation of graphite, introducing molecules of oxygen to the pure carbon graphene, and the oxidation reaction occurs between the graphene and the concentrated sulfuric acid with the potassium permanganate and sodium nitrate acting as catalysts. ${ }^{22}$ However, here it was not used sodium nitrate. In addition, our methodology does not promote complete exfoliation of FCF. Our goal is just oxidize partially the surface. For this, chemical surface treatment is carried out by immersion of FCF in a $\mathrm{H}_{2} \mathrm{SO}_{4} / \mathrm{KMnO}_{4}$ solution and the
FCF is kept in an ultrasound bath for 3 hours. Regarding contamination, there is no residual $\mathrm{MnO}_{2}$ on FCF surface, at least not detectable by XPS. The permanganate ion oxidizes the fibers, and according to the XPS results, they mainly promote the increase of the carbonyl group, with a decrease in hydroxyl groups. So far, it is too early to affirm that there is formation of a "specific quinone", especially those most active for oxidation of NADH (i.e., ortho-quinone). Also, permanganate ion could react with carbon-carbon double bonds to give a metal-oxide complex. ${ }^{23}$ Although permanganate ion has been extensively used and studied as an oxidant, there is considerable controversy concerning the oxidation state of the manganese species observed during the oxidation of carbon-carbon double bond..$^{23,24}$ In another way, treatments for the purification and cutting of carbon nanotubes with potassium permanganate in either acidic or alkaline conditions allow a controllable degree of oxidation, where the quinone groups formed are intermediates towards oxidation to carboxylic acids in a further step. ${ }^{24,25}$ There are several models of graphite oxide structures as presented in literature. ${ }^{26}$ Even though we will not use some of those models, the following results (mainly the voltammetry profile) show that the electrooxidation of NADH on FCFO
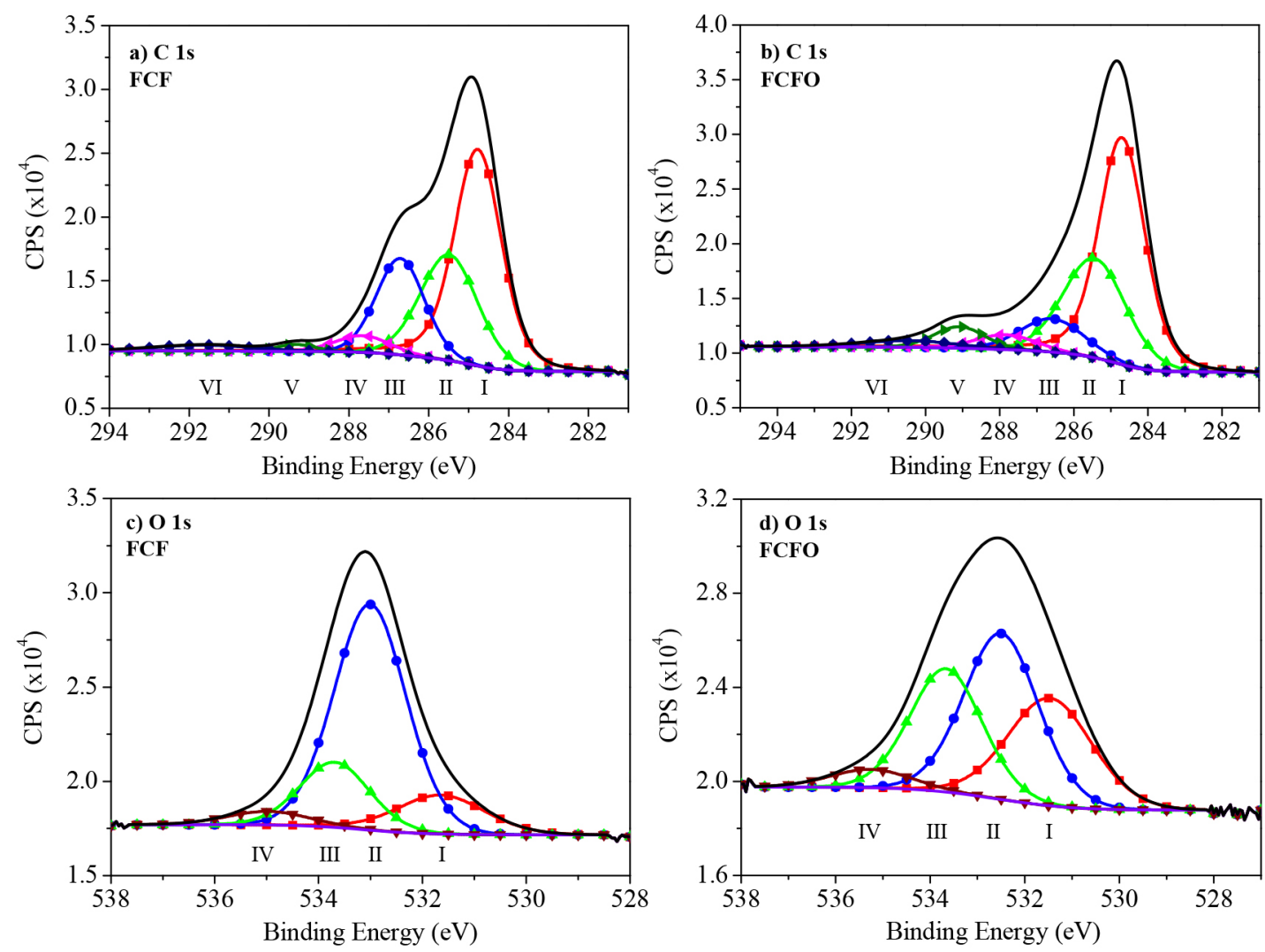

Figure 3. Deconvoluted XPS spectra. (a) and (c) pristine FCF and (b) and (d) FCFO. (a) and (b) shows the C 1s spectrum and figures;

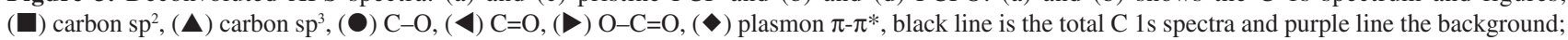
(c) and (d) shows $\mathrm{O} 1 \mathrm{~s}$ spectrum; $(\mathbf{O}) \mathrm{C}-\mathrm{O},(\boldsymbol{\square}) \mathrm{C}=\mathrm{O},(\boldsymbol{)}) \mathrm{O}-\mathrm{C}=\mathrm{O},(\boldsymbol{\nabla})$ adsorbed water molecules, black line is the total $\mathrm{O}$ 1s spectra and purple line the background. 
strongly suggests that quinones-like structures may be involved in the electron mediation process.

\section{FCFO play important role on NADH oxidation}

Before showing the results related to NADH oxidation on FCFO, it is important to understand the context of our finds. For the bioelectrocatalysis with ADH, NADH is oxidized with the conversion of ethanol in acetaldehyde. In this case, $\mathrm{NAD}^{+}$is the coenzyme and it is converted to $\mathrm{NADH}$, which is electrooxidized. The NAD ${ }^{+}$reaction and ethanol oxidation is represented by the simplified reaction shown in equation 1.

$$
\mathrm{CH}_{3} \mathrm{CH}_{2} \mathrm{OH}+\mathrm{NAD}+\mathrm{CH}_{3} \mathrm{CHO}+\mathrm{NADH}+\mathrm{H}^{+}
$$

Our goal is to achieve bioelectrooxidation of ethanol, using ADH immobilized by simple physical adsorption on a FCFO electrode, and show that the bioelectrocatalysis is enhanced by FCFO electrode. Also, it is not our intentions (or avoid that) to use other co-immobilizers or redox mediators in solution. The methodology proposed here is robust, easy to handle, and it does not require the use of other complementary materials, such as carbon nanotubes, graphene, nanoparticles, etc. Thus, the FCFO-ADH is the first in this category, in which only the surface oxidation method and enzyme immobilization are required.

XPS survey revealed that the oxidation can promotes the increase of $\mathrm{C}=\mathrm{O}$ groups on the $\mathrm{FCF}$. As we shall discuss, the electrochemistry of NADH oxidation on FCFO is quite similar to NADH oxidation on quinones-modified electrodes. It appears consensus that the modification of the electrode surfaces with quinones can improve the NADH electrooxidation, ${ }^{27,28}$ thus enhancing the bioelectrocatalysis based on NAD-dependent enzymes. ${ }^{28,29}$ Figure 4 shows the cyclic voltammetry of FCF (Figure 4a) and FCFO (Figure 4b) in $0.001 \mathrm{~mol} \mathrm{~L}^{-1} \mathrm{NADH}$, where it can be observed the oxidation of NADH on both electrodes.

For FCF, it is observed $0.600 \mathrm{~V}$ for the onset potential, while this parameter corresponds to $0.090 \mathrm{~V}$ for FCFO. The current related to oxidation of NADH is 8 times higher for FCFO when compared with FCF (i.e., at $0.600 \mathrm{~V}$ ), as observed in Figure 4c. It is clear that the presence of oxides on FCFO surface affects drastically the NADH oxidation. It is important to note that the voltammogram profile and shape is very similar for the oxidation of $\mathrm{NADH}$ in presence of quinones-modified surfaces. ${ }^{29}$ Different mechanisms have been proposed for NADH oxidation in the presence of redox mediator, and as bioelectrocatalysis is concerned, redox mediators have been coupled with NAD-dependent enzymes. Several authors have exposed different scenarios
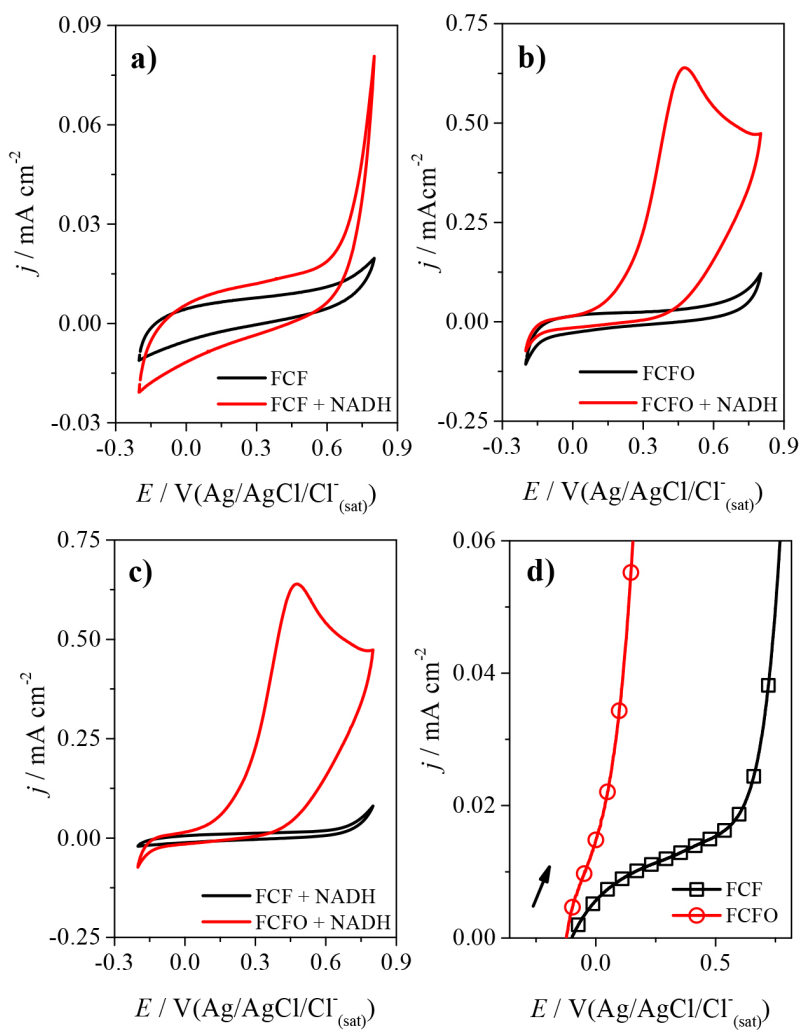

Figure 4. Cyclic voltammograms of (a) FCF and (b) FCFO, both in absence of NADH (black line) and in presence of $0.001 \mathrm{~mol} \mathrm{~L}^{-1}$ of $\mathrm{NADH}$ (red line); (c) FCF (black line) and FCFO (red line) in presence of $0.001 \mathrm{~mol} \mathrm{~L}^{-1}$ of NADH in $\mathrm{N}_{2}$-saturated $0.10 \mathrm{~mol} \mathrm{~L}^{-1}$ sodium phosphate buffer ( $\mathrm{pH} 7.5$ ), scan rate: $5 \mathrm{mV} \mathrm{s}^{-1}$, temperature: $25^{\circ} \mathrm{C}$; (d) zoomed region of onset potential.

involving the mediated electron transfer, but it seems to be a consensus that the chemical nature of these can lead to different paths. ${ }^{15}$ For instance, the common classifications can be related to an intermolecular complex between NADH and mediator (dyes), ${ }^{30,31}$ a net hydride transfer (quinones) ${ }^{28,32,33}$ and two one-electron steps with a proton transfer to the solvent (polyoxometallates)..$^{34,35}$

\section{Cyclic voltammetry and bioelectrocatalysis of ethanol}

Now, we show the bioelectrochemistry of ADH immobilized on FCFO electrode. It is important highlight that $\mathrm{ADH}$ is a redox enzyme that catalyzes the oxidation of primary and secondary alcohols to aldehydes and ketones, respectively. ${ }^{36}$ For instance, this enzymatic reaction can be utilized for determination of ethanol in alcoholic beverages and food, and has applications in forensic science and toxicology. ${ }^{37,38} \mathrm{ADH}$ is found in many microorganisms, such as in yeast and the liver of animals. ADH has a high specificity for ethanol and is very stable when isolated from the yeast, Saccharomyces cerevisiae, which was first purified and crystallized by Negelein and Wulff ${ }^{39}$ in 
1937. The molecular weight of ADH is $150 \mathrm{kDa}$. It has a tetrameric structure with one $\mathrm{NAD}^{+}$(nicotinamide adenine dinucleotide) as coenzyme and $\mathrm{Zn}^{2+}$ atom as cofactor in each subunit of the enzyme..$^{40}$ Each of these components is important for the mechanism of enzymatic catalysis. The features described above make ADH a good enzyme for use in bioanodes of biofuel cells. ${ }^{36,38}$

Figure 5 shows the electrochemistry of FCF-ADH (Figures 5a and 5b) and FCFO-ADH (Figures 5c and 5d). Black line corresponds to cyclic voltammograms in absence of ethanol. Subsequent cyclic voltammograms were obtained in presence of ethanol up to $0.41 \mathrm{~mol} \mathrm{~L}^{-1}$ for FCF-ADH and $0.92 \mathrm{~mol} \mathrm{~L}^{-1}$ for FCFO-ADH. The onset potential for ethanol oxidation is $0.630 \mathrm{~V}$ for FCF-ADH and $0.250 \mathrm{~V}$ for FCFO-ADH. For FCFO-ADH, the substrate saturation is achieved in presence of higher ethanol concentration than for FCF-ADH. In order to verify the influence of $\mathrm{NAD}^{+}$, cyclic voltammograms were recorded using FCFO-ADH in the absence of $\mathrm{NAD}^{+}$. A catalytic current from ethanol oxidation was not observed (data not shown). A faradaic current from $\mathrm{NAD}^{+}$on the FCFO electrode in the presence of $0.6 \mathrm{mmol} \mathrm{L}^{-1} \mathrm{NAD}^{+}$ and $0.49 \mathrm{~mol} \mathrm{~L}^{-1}$ of ethanol (without $\mathrm{ADH}$ ), was also not observed, indicating that the ethanol oxidation, in the present potential range, occurs just in the presence of $\mathrm{ADH}$.
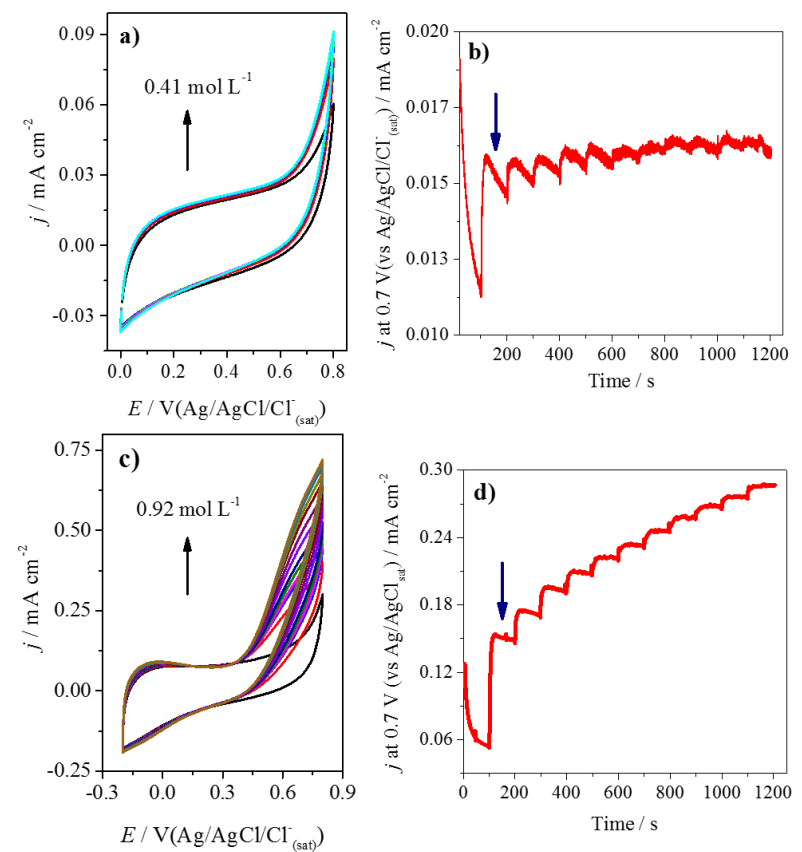

Figure 5. (a) Cyclic voltammograms of pristine FCF-ADH and (b) amperometric response in the presence of several ethanol concentrations by using the same electrode; (c) cyclic voltammograms of FCFO-ADH and (d) amperometric response for increasing ethanol concentration for FCFO-ADH. All measurements were carried out in $\mathrm{N}_{2}$-saturated, $0.1 \mathrm{~mol} \mathrm{~L}^{-1}$ sodium phosphate buffer $(\mathrm{pH} 7.5)$ containing $0.6 \mathrm{mmol} \mathrm{L}^{-1}$ $\mathrm{NAD}^{+}$at $25{ }^{\circ} \mathrm{C}$. For cyclic voltammograms: scan rate: $50 \mathrm{mVs}^{-1}$, and for chronoamperometry: applied potential: $0.7 \mathrm{~V}\left(v s . \mathrm{Ag} / \mathrm{AgCl}^{-\mathrm{Cl}^{-}}{ }_{\text {(sat) }}\right)$.
Thus, as expected, $\mathrm{NAD}^{+}$and $\mathrm{FCFO}-\mathrm{ADH}$ is required for ethanol oxidation.

It has not escaped our notice that the equation 1 refers to global reaction of ethanol oxidation catalyzed by ADH. However, approaches more sophisticated related to the kinetic mechanism of ADH have been described in several studies. ${ }^{41-47}$ As reactions pathways are concerned, enzyme follows the steady-state random mechanism on the alcohol side, and a steady-state ordered mechanism on the aldehyde side of the catalytic cycle. For the ethanol oxidation, ADH typically operates by a random bi-bi mechanism with a preferred order of addition of reactants on the alcohol side of the reaction, and with the dissociation of coenzyme in the reaction. The steps involved in this mechanism are illustrated in Figure 6. The alcohol-NAD ${ }^{+}$reactions indicate that some dissociations of coenzyme by active ternary complex enzyme-NAD ${ }^{+}$-alcohol should occur. Thus, coenzyme probably first binds to the enzyme (ADH-NAD $)$, with subsequent substrate binding (ADH-ethanol), thereby forming a ternary complex (ADH-NAD+-ethanol). In the structure of $\mathrm{ADH}$, the adenosine binding site is easily available to the solution, while the substrate binding site situated next to the zinc atom and inside the enzyme structure is quite narrow and almost inaccessible to the solution. After an intramolecular reaction, with the formation of acetaldehyde molecules and NADH species, the ADH-acetaldehyde-NADH complex is formed. The

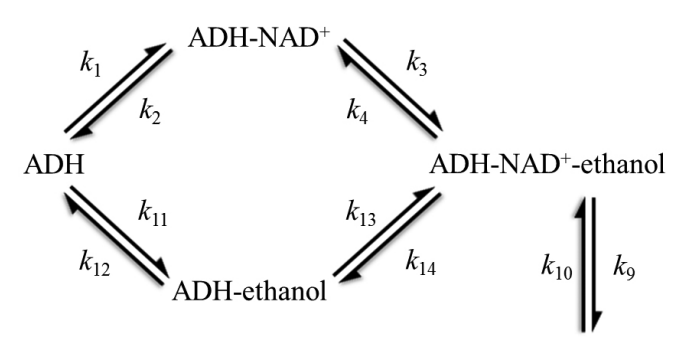

$\mathrm{ADH}$-acetaldehyde-NADH<smiles>CC(C)(C)[Ge](C)(C)C(C)(C)C</smiles>

ADH-NADH

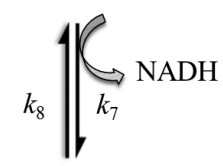

$\mathrm{ADH}$

Figure 6. Mechanism for ADH enzyme. This is an illustrated rereading of the mechanism proposed pioneering by Dickenson and Dickinson, ${ }^{42}$ where the authors carried out the kinetics of ethanol oxidation by $\mathrm{NAD}^{+}$, and acetaldehyde and butyraldehyde reduction by NADH. If NADH dissociation from ADH-NADH complex is the limiting step $\left(\mathrm{k}_{7}\right)$, it can infers that the oxidation of NADH released from this reaction can be used to calculate kinetics parameters from electrochemical steady-state data. 
rate-limiting step of ethanol oxidation at neutral $\mathrm{pH}$, is not the chemical reactions $\left(\mathrm{k}_{9}\right)$, but the dissociation of NADH from the ADH-NADH complex $\left(\mathrm{k}_{7}\right)$. Likewise, $\mathrm{NAD}^{+}$ coenzyme is released much faster from the ADH-NAD ${ }^{+}$ complex $\left(\mathrm{k}_{2}\right)$ than NADH dissociates from the ADH-NADH complex $(\mathrm{ADH}-\mathrm{NADH} \rightleftharpoons \mathrm{ADH}+\mathrm{NADH}) .{ }^{45,47}$ Eys et al ${ }^{48}$ report that the regeneration of enzyme-NADH complex is accompanied by a direct competition between NADH and $\mathrm{NAD}^{+}$to the active site of enzyme.

In terms of kinetic analysis, the $\mathrm{NAD}^{+}$coenzyme is treated as a co-substrate. The binding energies for the step between $\mathrm{NAD}^{+}$and the free enzyme $\left(\mathrm{ADH}+\mathrm{NAD}^{+}\right.$

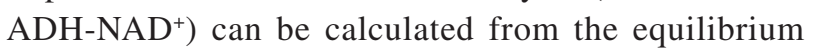
constant $\mathrm{k}_{1} / \mathrm{k}_{2}$. In the case of NADH dissociation, the binding energies for NADH can be calculated from the equilibrium constant $\mathrm{k}_{8} / \mathrm{k}_{7}$ (Figure 6). Finally, the ratios of rate constants $\mathrm{k}_{1} / \mathrm{k}_{2}$ and $\mathrm{k}_{8} / \mathrm{k}_{7}$ may be identified with the equilibrium association constant for the binding of $\mathrm{NAD}^{+}$or NADH to the free enzyme, respectively. ${ }^{49}$ Therefore, once that the step of NADH dissociation from ADH-NADH complex is the limiting step, the oxidation of NADH released from this reaction could be used to calculate kinetic parameters. To confirm the better performance of FCFO-ADH, Figures $5 \mathrm{~b}$ and $5 \mathrm{~d}$ shows current-time transient at $0.700 \mathrm{~V}$ during $1200 \mathrm{~s}$ with FCF-ADH (Figure 5b) and FCFO-ADH (Figure 5d), both in the presence of several concentrations of ethanol. The applied potential was chosen because it is the value at which the current reaches a quasi-steady state for the oxidation of ethanol. As observed in Figure 5, the increase in the current when the ethanol concentration increases is higher for FCFO-ADH. Each ethanol addition (blue arrow) corresponds to $200 \mu \mathrm{L}$ of ethanol $50 \%(\mathrm{v} / \mathrm{v})$. The apparent Michaelis-Menten constant $\left(\mathrm{K}_{\mathrm{M}}\right.$ app), which gives an indication of the enzyme-substrate kinetics, can be obtained using equation 2, the electrochemical version of the Lineweaver-Burk equation. ${ }^{50,51}$

$$
\frac{1}{\mathrm{I}_{\mathrm{SS}}}=\frac{1}{\mathrm{I}_{\max }}+\frac{\mathrm{K}_{\mathrm{M}}^{\mathrm{app}}}{\mathrm{I}_{\max }} \frac{1}{\mathrm{c}}
$$

where $I_{S S}$ is the steady-state current after the addition of substrate, $I_{\max }$ is the maximum current measured under saturated substrate conditions, and $\mathrm{c}$ is the bulk concentration of substrate. $\mathrm{K}_{\mathrm{M}}$ app was found to be $0.26 \mathrm{mmol} \mathrm{L}^{-1}$ for FCFO-ADH and $28.9 \mathrm{mmol} \mathrm{L}^{-1}$ for FCF-ADH. In a first approximation, this result suggests that for FCFO-ADH the enzyme is highly active. If we consider the general concept of Michaelis-Menten kinetics, $\mathrm{ADH}$ have varying tendencies to bind their ethanol substrate (affinities), thus the ADH's $\mathrm{K}_{\mathrm{M}}$ describes the substrate concentration at which half of the active sites of the enzyme are occupied by ethanol. Examples of other values reported in the literature are $0.91 \mathrm{mmol} \mathrm{L}^{-1}$ for a glassy carbon electrode modified with toluidine blue diazonium salt, ${ }^{51} 0.38 \mathrm{mmol} \mathrm{L}^{-1}$ for multiwalled carbon nanotubechitosan-alcohol dehydrogenase nano-biocomposite, ${ }^{52}$ and $4.95 \mathrm{mmol} \mathrm{L}^{-1}$ for colloidal gold-carbon nanotubecomposite electrode ${ }^{53}$ Note that all of these systems used some kind of the material at electrode/enzyme interface, either nanotubes, redox mediators, or something else. These facts reinforce the importance of our results obtained with FCFO-ADH.

\section{Effect of $\mathrm{pH}$ and temperature on the bioelectroactivity}

With high stability and bioelectroactivity, FCFO-ADH is a very promising candidate for use in cyclic voltammetry experiments and it can be used to determine thermodynamics and kinetics properties of $\mathrm{ADH}$, for instance optimum temperature and optimum $\mathrm{pH}$. Our goals from here are to show the application capability of FCFO electrode for this purpose.

The temperature dependence of ethanol oxidation was investigated, as shown in Figures 7a, 7c and 7e. The temperature stability of ADH on FCFO was determined by observing the remaining oxidative activity for ethanol after a $10 \mathrm{~min}$ incubation period at temperatures between 10 and $60{ }^{\circ} \mathrm{C}$. The oxidation current for ethanol using the FCFO-ADH electrode increases the catalytic current density from 10 to $40^{\circ} \mathrm{C}$. The current density is 4-times higher at $40^{\circ} \mathrm{C}\left(0.58 \pm 0.03 \mathrm{~mA} \mathrm{~cm}^{-2}\right)$ than it is at $10^{\circ} \mathrm{C}$ (Figure $7 \mathrm{c}$ ). At a very first analysis, this increase in the catalytic current density can be caused by the enhanced activity of the enzyme and the increased ethanol reaction rate at higher temperatures. Above $40^{\circ} \mathrm{C}$, however, the catalytic current density decreases in a quasi-linear profile. At $60{ }^{\circ} \mathrm{C}$, the current density is 7-times lower $\left(0.079 \pm 0.004 \mathrm{~mA} \mathrm{~cm}^{-2}\right)$ than it is at $40^{\circ} \mathrm{C}$. In addition, it was analyzed the variation of the onset potential with the temperature (Figure 7e), once for bioanodes is interesting the lower onset potential as possible, and the lowest onset potential was obtained at $45^{\circ} \mathrm{C}$. These results are in agreement with data reported in the literature for homogeneous catalysis using $\mathrm{ADH} .^{54,55}$ However, as bioelectrocatalysis is concerned, it is the first time that the optimum temperature at $40^{\circ} \mathrm{C}$ is obtained for $\mathrm{ADH}$ in a non-mediated electrode reaction.

The $\mathrm{pH}$ dependence for ethanol oxidation was investigated, as shown in Figures $7 \mathrm{~b}, 7 \mathrm{~d}$ and $7 \mathrm{f}$, once the protonation of protein structure plays important role for the optimum conditions for bioelectrocatalysis. The measurements were carried out varying the $\mathrm{pH}$ of the electrolyte from 6.0 to 9.0, as shown in Figure 7b, which 

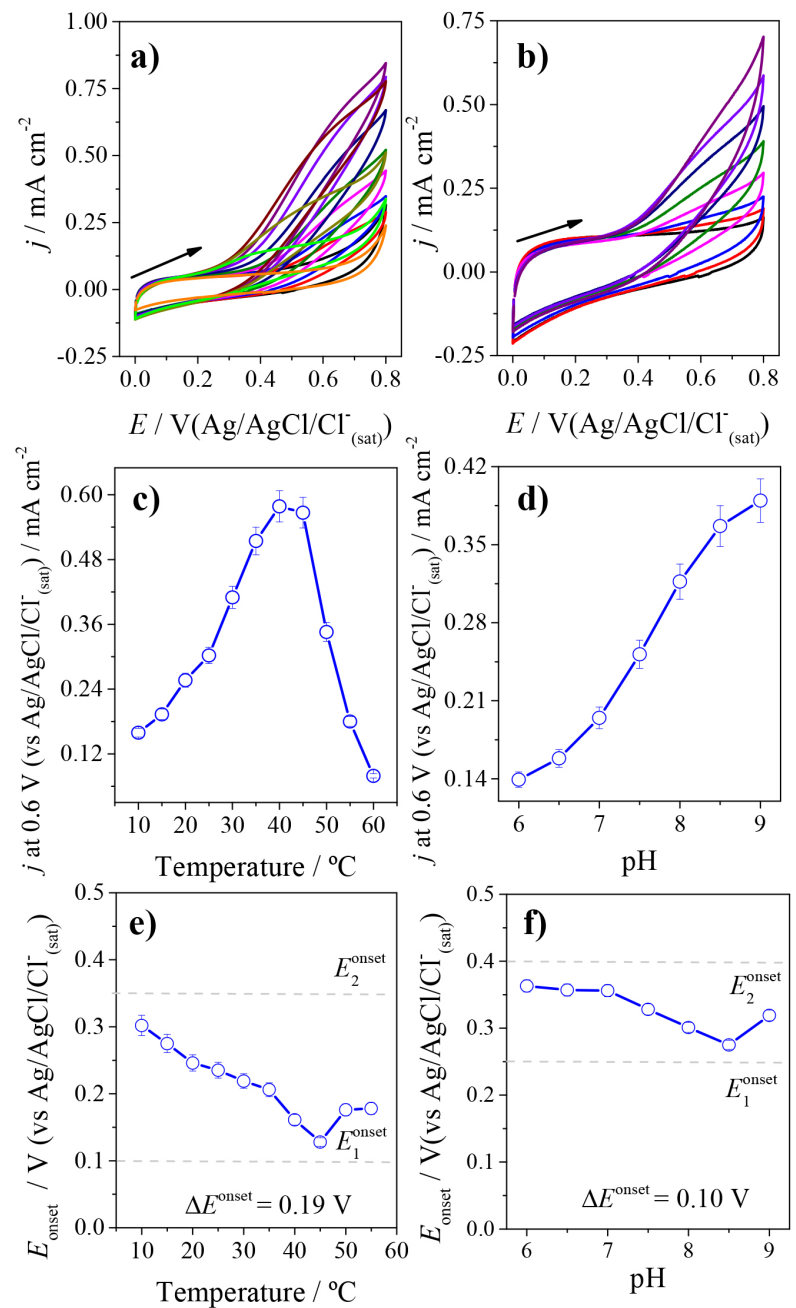

Figure 7. (a) Cyclic voltammograms of the FCFO-ADH bioelectrode in $\mathrm{N}_{2}$-saturated $0.1 \mathrm{~mol} \mathrm{~L}^{-1}$ sodium phosphate buffer $(\mathrm{pH}$ 7.5) containing $0.6 \mathrm{mmol} \mathrm{L}^{-1} \mathrm{NAD}^{+}$without ethanol (black line) and with $0.25 \mathrm{~mol} \mathrm{~L}^{-1}$ of ethanol at different temperatures. Scan rate: $50 \mathrm{mVs}^{-1}$; (b) cyclic voltammograms of the FCFO-ADH bioelectrode in $\mathrm{N}_{2}$-saturated $0.1 \mathrm{~mol} \mathrm{~L}^{-1}$ sodium phosphate buffer containing $0.6 \mathrm{mmol} \mathrm{L}^{-1} \mathrm{NAD}^{+}$ without ethanol (black line) and with $0.25 \mathrm{~mol} \mathrm{~L}^{-1}$ of ethanol at different $\mathrm{pH}$. Scan rate: $50 \mathrm{mVs}^{-1}$; (c) plot of temperature versus current density of ethanol oxidation at $0.6 \mathrm{~V} v s . \mathrm{Ag} / \mathrm{AgCl} / \mathrm{Cl}^{-}{ }_{\text {(sat) }}$; (d) plot of $\mathrm{pH}$ versus current density of ethanol oxidation at $0.6 \mathrm{~V} v s$. $\mathrm{Ag} / \mathrm{AgCl} / \mathrm{Cl}^{-}{ }_{\text {(sat) }}$; (e) plot of temperature versus onset potential of ethanol oxidation; (f) plot of $\mathrm{pH}$ versus onset potential of ethanol oxidation.

cyclic voltammograms were recorded at $50 \mathrm{mV} \mathrm{s}^{-1}$. In the case of $\mathrm{ADH}$, it is sensitive to $\mathrm{pH}$ variation because the $\mathrm{H}^{+}$on the enzyme environment affects binding between enzyme and its substrate, catalytic activity of the enzyme, and mainly the protein structure. ${ }^{56}$ Furthermore, this dependence with the $\mathrm{pH}$ may have a contribution of the NADH oxidation on FCFO, once we have observed that the electrochemical process is $\mathrm{pH}$ dependent (not shown). The catalysis of ethanol oxidation by ADH occurs with the reduction of $\mathrm{NAD}^{+}$and $\mathrm{ADH}$ transfers one proton and two electrons ${ }^{57}$ from ethanol to $\mathrm{NAD}^{+}$, utilizing $\mathrm{Zn}^{2+}$ and $\mathrm{NAD}^{+}$ coenzymes. As illustrated in Figure 8, $\mathrm{Zn}^{2+}$ is maintained by three amino acids (two cysteine and one histidine), which stabilizes enzyme structure allowing proton transference in this reaction.

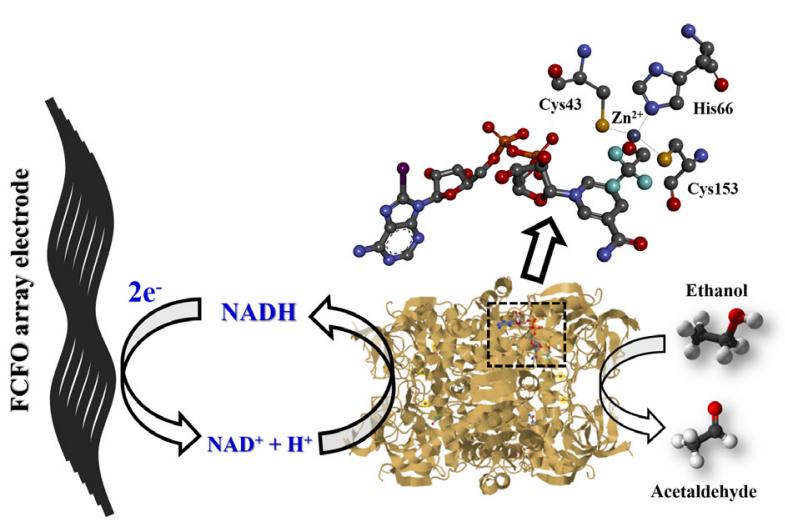

Figure 8. Schematic illustration for ethanol oxidation on FCFO-ADH electrode. ADH is a homotetramer of subunits with 347 amino acid residues (PDB 4W6Z). The catalysis of ethanol oxidation by ADH occurs with the reduction of $\mathrm{NAD}^{+}$. $\mathrm{ADH}$ transfers one proton and two electrons from ethanol to $\mathrm{NAD}^{+}$, utilizing $\mathrm{Zn}^{2+}$ and $\mathrm{NAD}^{+}$coenzymes present in its structure. $\mathrm{Zn}^{2+}$ is maintained by three amino acids, two cysteine and one histidine, highlighted above the enzyme structure. One time available, NADH is oxidized catalytically on FCFO electrode.

If we observe the voltammograms in extreme values carefully, we will begin to notice differences that are more evident. Thus, the effects of $\mathrm{pH}$ and temperature highlighting the extreme values $(\mathrm{pH} 6.0$ and 9.0 and temperatures 10 and $40^{\circ} \mathrm{C}$ ) have been considered, as shown in Figure 9.

Figure 9a shows the cyclic voltammograms of FCFO-ADH in presence of $0.6 \mathrm{mmol} \mathrm{L}^{-1} \mathrm{NAD}^{+}$(grey line) and $0.25 \mathrm{~mol} \mathrm{~L}^{-1}$ ethanol at $\mathrm{pH} 6.0$ (red line) and $\mathrm{pH} 9.0$ (purple line), while Figure $9 \mathrm{~b}$ evidence the region of the onset potential. We observed a subtle difference in the onset potential when the $\mathrm{pH}$ was altered $\left(\Delta \mathrm{E}^{\text {onset }}=0.100 \pm 0.007 \mathrm{~V}\right)$, while the current densities increase a lot in the same range. On the other side, for temperature dependence (Figures $9 \mathrm{c}$ and $9 \mathrm{~d}$ ), a decrease in the onset potential is observed when the temperature increases $\left(\Delta \mathrm{E}^{\text {onset }}=0.180 \pm 0.006 \mathrm{~V}\right)$; this is accompanied by a corresponding decrease in the current density.

Thus, we show that it is possible to evaluate both the effect of temperature and the $\mathrm{pH}$ on the electrochemistry of ADH. We do not show here any modeling or molecular interpretation of these effects, because our intention is to evaluate the properties of FCFO front ADH immobilization. However, the results herein open new possibilities to use protein film voltammetry for future studies of enzyme kinetics to elucidate mechanism of catalysis or inhibition, for instance. In this case, steady-state polarization could be applied successfully. Our research group has 

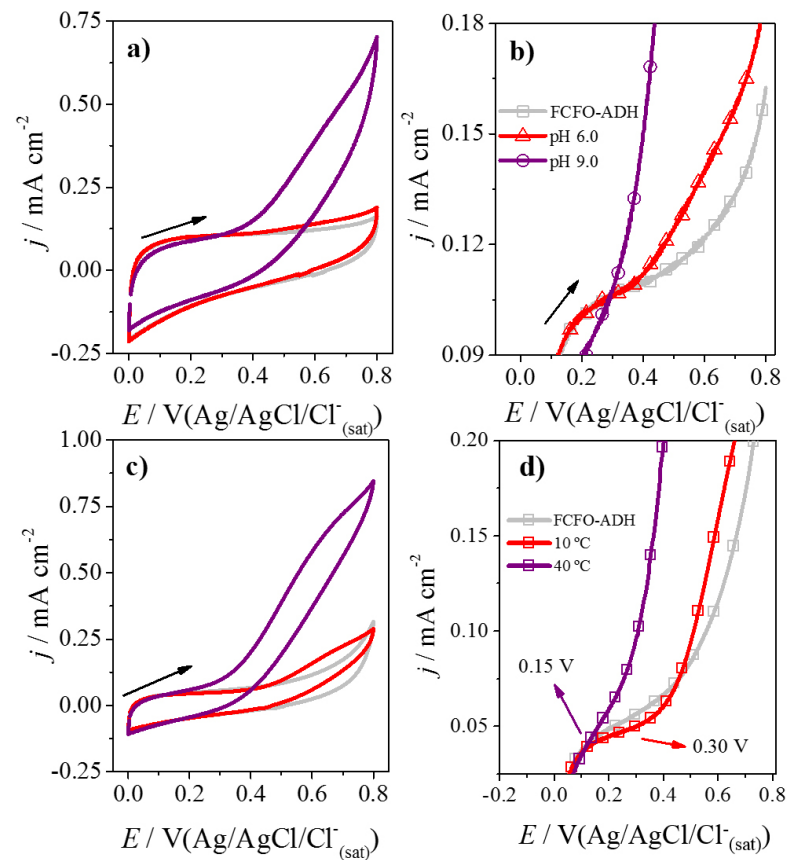

Figure 9. (a) Cyclic voltammograms of the FCFO-ADH bioelectrode in $\mathrm{N}_{2}$-saturated $0.1 \mathrm{~mol} \mathrm{~L}^{-1}$ sodium phosphate buffer containing $0.6 \mathrm{mmol} \mathrm{L}^{-1}$ $\mathrm{NAD}^{+}$without ethanol (grey line) and with $0.25 \mathrm{~mol} \mathrm{~L}^{-1}$ of ethanol at pH 6.0 (red line) and $\mathrm{pH} 9.0$ (purple line); (b) cyclic voltammograms of the FCFO-ADH bioelectrode in $\mathrm{N}_{2}$-saturated 0.1 mol L$^{-1}$ sodium phosphate buffer ( $\mathrm{pH} 7.5$ ) containing $0.6 \mathrm{mmol} \mathrm{L}^{-1} \mathrm{NAD}^{+}$without ethanol (grey line) and with $0.25 \mathrm{~mol} \mathrm{~L}^{-1}$ of ethanol at 10 (red line) and $40^{\circ} \mathrm{C}$ (purple line), scan rate: $50 \mathrm{mVs}^{-1}$; (c) plot of temperature versus current density of ethanol oxidation at $0.6 \mathrm{~V} v s$. $\mathrm{Ag} / \mathrm{AgCl} / \mathrm{Cl}^{-}$(sat) ; (d) plot of $\mathrm{pH}$ versus current density of ethanol oxidation at $0.6 \mathrm{~V} v \mathrm{~s}$. $\mathrm{Ag} / \mathrm{AgCl}^{-\mathrm{Cl}^{-}}{ }_{\text {(sat) }}$; (e) plot of temperature versus onset potential of ethanol oxidation; (f) plot of $\mathrm{pH}$ versus onset potential of ethanol oxidation.

conducted some experiments of this nature (not shown) and encouraging results are being observed. Thus, here there is a proof of concept that the FCFO-ADH electrode can be used for fundamental studies of enzyme kinetics.

\section{Conclusions}

We investigated the application of wet chemical treatment to prepare oxidized flexible carbon fibers, named here as FCFO. From XPS data, it was found clear evidence that the permanganate ions used in the treatment method promoted an increase in carbonyl group on fiber surface. Probably, the presence of $\mathrm{C}=\mathrm{O}$ species is responsible to enhance the electrooxidation of NADH. We believe that the presence of quinones cannot be ruled out, although additional experiments design for this purpose should be carried out. When FCFO-ADH was applied as a bioelectrode, ethanol could be oxidized at $0.250 \mathrm{~V}$ (vs. $\mathrm{Ag} / \mathrm{AgCl} / \mathrm{Cl}^{-}{ }_{\text {(sat) }}$ ). FCFO-ADH showed high stability and bioelectroactivity, which enabled this bioelectrode to be used in cyclic voltammetry experiments. Therefore, the bioelectrooxidation of ethanol by $\mathrm{ADH}$ in the presence of
$\mathrm{NAD}^{+}$and in different conditions of $\mathrm{pH}$ and temperature accredits it as a prospective bioelectrode to develop enzyme biofuel cells.

\section{Acknowledgments}

The authors gratefully acknowledge the financial support provided by FAPESP (F. N. Crespilho, project No.: 2015/16672-3 and 2013/14262-7), CNPq (F. N. Crespilho, project No. 478525/2013-3), National Institute of Science and Technology in Organic Electronics (INCT-INEO, Brazil), and Nanomedicine Network (NanoBioMed-Brazil, CAPES). The authors thank Prof Peter Hammer (LEFE) and LCE-DEMa for XPS and FEG-SEM facilities, respectively. A. R. Pereira acknowledges FAPESP (Doctoral Fellowship No. 2013/19908-2) for support.

\section{References}

1. Mc Creery, R. L.; Chem. Rev. 2008, 108, 2646.

2. Brownson, D. A. C.; Kampouris, D. K.; Banks, C. E.; Chem. Soc. Rev. 2012, 41, 6944.

3. Frank, E.; Hermanutz, F.; Buchmeiser, M. R.; Macromol. Mater. Eng. 2012, 297, 493.

4. Martins, M. V. A.; Pereira, A. R.; Luz, R. A. S.; Iost, R. M.; Crespilho, F. N.; Phys. Chem. Chem. Phys. 2014, 16, 17426.

5. Chen, T.; Barton, S. C.; Binyamin, G.; Gao, Z. Q.; Zhang, Y. C.; Kim, H. H.; Heller, A.; J. Am. Chem. Soc. 2001, 123, 8630.

6. Koushanpour, A.; Guz, N.; Gamella, M.; Katz, E.; ECS J. Solid State Sci. Technol. 2016, 5, M3037.

7. de Souza, J. C. P.; Iost, R. M.; Crespilho, F. N.; Biosens. Bioelectron. 2015, 77, 860 .

8. Updike, S. J.; Hicks, G. P.; Nature 1967, 214, 986.

9. Sales, F. C. P. F.; Iost, R. M.; Martins, M. V. A.; Almeida, M. C.; Crespilho, F. N.; Lab Chip 2013, 13, 468.

10. Iost, R. M.; Sales, F. C. P. F.; Martins, M. V. A.; Almeida, M. C.; Crespilho, F. N.; ChemElectroChem 2015, 2, 518.

11. Pereira, A. R.; de Souza, J. C. P.; Iost, R. M.; Sales, F. C. P. F.; Crespilho, F. N.; J. Electroanal. Chem. 2016, 780, 396.

12. Luz, R. A. S.; Pereira, A. R.; de Souza, J. C. P.; Sales, F. C. P. F.; Crespilho, F. N.; ChemElectroChem 2014, 1, 1751.

13. Elving, P. J.; Schmakel, C. O.; Santhanam, K. S. V.; Zuman, P.; Crit. Rev. Anal. Chem. 1976, 6, 1.

14. Moiroux, J.; Elving, P. J.; Anal. Chem. 1978, 50, 1056.

15. Popescu, I. C.; Dominguez, E.; Narvaez, A.; Pavlov, V.; Katakis, I.; J. Electroanal. Chem. 1999, 464, 208.

16. Zare, H. R.; Golabi, S. M.; J. Electroanal. Chem. 1999, 464, 14.

17. Gorton, L.; Dominguez, E.; Rev. Mol. Biotechnol. 2002, 82, 371. 
18. Katz, E.; Lotzbeyer, T.; Schlereth, D. D.; Schuhmann, W.; Schmidt, H. L.; J. Electroanal. Chem. 1994, 373, 189.

19. Reuillard, B.; le Goff, A.; Cosnier, S.; Anal. Chem. 2014, 86, 4409.

20. Abdellaoui, S.; Milton, R. D.; Quah, T.; Minteer, S. D.; Chem. Commun. 2016, 52, 1147.

21. Iost, R. M.; Crespilho, F. N.; Biosens. Bioelectron. 2012, $31,1$.

22. Hummers, W. S.; Offeman, R. E.; J. Am. Chem. Soc. 1958, 80, 1339.

23. Freeman, F.; Kappos, J. C.; J. Am. Chem. Soc. 1985, 107, 6628.

24. Dash, S.; Patel, S.; Mishra, B. K.; Tetrahedron 2009, 65, 707.

25. Zhang, J.; Zou, H.; Qing, Q.; Yang, Y.; Li, Q.; Liu, Z.; Guo, X.; Du, Z.; J. Phys. Chem. B 2003, 107, 3712.

26. Szabo, T.; Berkesi, O.; Forgó, P.; Josepovits, K.; Sanakis, Y.; Petridis, D.; Dekany, I.; Chem. Mater. 2006, 18, 2740.

27. Tse, D. C. S.; Kuwana, T.; Anal. Chem. 1978, 50, 1315.

28. Carlson, B. W.; Miller, L. L.; J. Am. Chem. Soc. 1985, 107, 479.

29. Jaegfeldt, H.; Torstensson, A. B. C.; Gorton, L. G. O.; Johansson, G.; Anal. Chem. 1981, 53, 1979.

30. Persson, B.; Gorton, L.; J. Electroanal. Chem. 1990, 292, 115.

31. Gorton, L.; Johansson, G.; Torstensson, A.; J. Electroanal. Chem. 1985, 196, 81.

32. Fukuzumi, S.; Nishizawa, N.; Tanaka, T.; J. Org. Chem. 1984, 49, 3571 .

33. Jaegfeldt, H.; Kuwana, T.; Johansson, G.; J. Am. Chem. Soc. 1983, 105, 1805.

34. Keita, B.; Essaadi, K.; Nadjo, L.; Desmadril, M.; Chem. Phys. Lett. 1995, 237, 411.

35. Essaadi, K.; Nadjo, K. L.; J. Electroanal. Chem. 1994, 367, 275.

36. Kontani, A.; Masuda, M.; Matsumura, H.; Nakamura, N.; Yohda, M.; Ohno, H.; Electroanalysis 2014, 26, 682.

37. Cai, C. X.; Xue, K. H.; Zhou, Y. M.; Yang, H.; Talanta 1997, 44, 339.

38. Akyilmaz, E.; Dinckaya, E.; Talanta 2003, 61, 113.
39. Negelein, E.; Wulff, H.-J.; Biochem. Z. 1937, 293, 351.

40. Presecki, A. V.; Vasic-Racki, D.; Process Biochem. 2005, 40, 2781.

41. Dickinson, F. M.; Monger, G. P.; Biochem. J. 1973, 131, 261.

42. Dickenson, C. J.; Dikinson, F. M.; Biochem. J. 1975, 147, 303.

43. Klinman, J. P.; Crit. Rev. Biochem. Mol. Biol. 1981, 10, 39.

44. Ganzhorn, A. J.; Green, D. W.; Hershey, A. D.; Gould, R. M.; Plapp, B. V.; J. Biol. Chem. 1987, 262, 3754.

45. Trivic, S.; Leskovac, V.; J. Serb. Chem. Soc. 2000, 65, 207.

46. Abuin, E.; Lissi, E.; Leon, L.; Protein J. 2008, 27, 247.

47. Forti, J. C.; Neto, S. A.; Zucolotto, V.; Ciancaglini, P.; de Andrade, A. R.; Biosens. Bioelectron. 2011, 26, 2675.

48. Eys, J. V.; Ciotti, M. M.; Kaplan, N. O.; J. Biol. Chem. 1958, $231,571$.

49. Leskovac, V.; Trivic, S.; Pericin, D.; Popovic, M.; Kandrac, J.; J. Serb. Chem. Soc. 2010, 75, 185.

50. Cass, A. E. G.; Biosensors: A Practical Approach; IRL Press: Oxford, 1990.

51. Nasri, Z.; Shams, E.; Ahmadi, M.; Electroanalysis 2013, 25, 1917.

52. Lee, C. A.; Tsai, Y. C.; Sens. Actuators, B 2009, 138, 518.

53. Manso, J.; Mena, M. L.; Yáñez-Sedeño, P.; Pingarrón, J. M.; Electrochim. Acta 2008, 53, 4007.

54. Zanon, J. P.; Peres, M. F. S.; Gattas, E. A. L.; Enzyme Microb. Technol. 2007, 40, 466.

55. Neto, S. A.; Forti, J. C.; Zucolotto, V.; Ciancaglini, P.; de Andrade, A. R.; Process Biochem. 2011, 46, 2347.

56. Nelson, D. L.; Cox, M. M.; Principles of Biochemistry, $4^{\text {th }}$ ed.; Freeman and Co.: New York, 2005.

57. Cooney, M. J.; Svoboda, V.; Lau, C.; Martin, G.; Minteer, S. D.; Energy Environ. Sci. 2008, 1, 320.

Submitted: October 10, 2016

Published online: February 3, 2017 